\title{
Renal osteodystrophy: dietary influences and management
}

By Z. Varghese, K. Farrington and J. F. Moorhead, Department of Nephrology and Transplantation, Royal Free Hospital, Pond Street, London $\mathrm{NW}_{3}$

Our concepts of metabolic bone disease in chronic renal failure (CRF) have undergone considerable revision during the last two decades, mainly due to the rehabilitation of patients on dialysis, and to the greater understanding of the metabolism of vitamin D, parathyroid hormone (PTH) and other components of calcium and phosphate homoeostasis. Renal osteodystrophy is a pleomorphic disease, the clinical manifestations of which consist of osteomalacia, osteitis fibrosa, osteosclerosis, and osteoporosis. In an individual patient, any one of these lesions may exist alone or in various combinations, with one or the other lesion predominating (Kaye \& Silverman, r965; Ellis \& Peart, r973).

A number of factors have been implicated in the pathogenesis of renal osteodystrophy, including phosphate retention, hypocalcaemia, and secondary hyperparathyroidism (Bricker et al. 1969; Arnaud, 1973), vitamin D resistance (Liu \& Chu, 1943; Lumb et al. 1971), intestinal malabsorption of Ca (Coburn et al. 1973; Farrington, Varghese, Newman et al. 1979), skeletal resistance to the Ca mobilizating action of PTH (Massry et al. 1973; Massry et al. 1978), defects in the degradation of PTH (Hruska et al. 1975), metabolic acidosis (Cochran et al. 1973; Lee et al. 1977) and 'uraemic toxins' (Wills et al. 1975). Comprehensive reviews of the pathogenesis, clinical assessment and management of renal osteodystrophy have appeared recently (Kleeman \& Better, 1973; David, r975; Avioli, 1978; Pierides, 1978).

The present account makes special reference to dietary factors in the pathogenesis of renal osteodystrophy and its treatment.

\section{Vitamin $D$ metabolism}

Liu \& Chu (1943) initially proposed the concept of vitamin D resistance in CRF. They also reported that the skeletal lesions in their patients were indistinguishable from those seen in nutritional rickets. Stanbury et al. (1969) showed that azotaemic rickets can be cured by vitamin $\mathrm{D}$ alone, albeit in pharmacological doses. In untreated patients with renal osteodystrophy, the plasma level of assayable vitamin $\mathrm{D}$ has been reported to be normal or low due to dietary restrictions (Lumb et al. I97I). In Britain the state of vitamin D nutrition is considered to be only marginally adequate to protect against nutritional rickets and osteomalacia. Hence when chronic renal failure superimposes an increased requirement for vitamin $\mathrm{D}$, British patients are more likely to develop an effective vitamin $\mathrm{D}$ deficiency and osteomalacia than patients in the United States, whose vitamin $D$ nutrition is better. Differences in vitamin $D$ nutrition and sunlight exposure may affect the clinical presentation of renal osteodystrophy. 
Several mechanisms have been proposed for this vitamin D resistance. These include: failure of endorgan responsiveness due to uraemia (Brickman et al. 1974), increased metabolic turnover of vitamin D (Avioli et al. 1968), depletion of 25-OHD (Offerman et al. 1974) and a deficiency of $1,25-(\mathrm{OH})_{2} \mathrm{D}_{3}$ (Mawer $e t$ al. 1973; Haussler, 1975 ). It is now generally agreed that vitamin $D_{3}$ must undergo a two-stage metabolic transformation; first in the liver to $25-\mathrm{OHD}_{3}$ and then in the kidney to $1,25-(\mathrm{OH})_{2} \mathrm{D}_{3}$ and other metabolites, before it can express its full potential as a steroid hormone (DeLuca, 1973).

Increased hepatic microsomal enzyme induction has been implicated in the depletion of $25-\mathrm{OHD}_{3}$ and the pathogenesis of osteomalacia in CRF (Eastwood et al. 1976). However, the low levels of $25-\mathrm{OHD}$ found in undialysed patients may well be a consequence of dietary restriction (Mawer et al. 1973), and other studies suggest that hepatic metabolism of vitamin $D$ is normal in these patients (Farrington et al. 1979). Identification of the kidney as the sole site for the conversion of $25-\mathrm{OHD}_{3}$ to its active form- $-1,25-(\mathrm{OH})_{2} \mathrm{D}_{3}$ has provided an explanation for the nature of 'vitamin $D$ resistance' in CRF. However, some observations are inconsistent with the view that a deficiency of $1,25-(\mathrm{OH})_{2} \mathrm{D}_{3}$ is solely responsible for the pathogenesis of renal osteodystrophy. (Bordier et al. 1973.) Recently, Eastwood et al. (1979) demonstrated that manifestations of nutritional vitamin $D$ deficiency can occur in the presence of normal concentrations of $1,25-(\mathrm{OH})_{2} \mathrm{D}_{3}$. This is analogous to the situation in anticonvulsant induced osteomalacia (Jubiz et al. 1977).

It may thus be that the various metabolites of vitamin $\mathrm{D}$ have different roles to perform in the total expression of its biological potential, $25-\mathrm{OHD}_{3}$ and $24,25-$ $(\mathrm{OH})_{2} \mathrm{D}_{3}$ may be involved in normal mineralization, whereas $\mathrm{I}, 25-(\mathrm{OH})_{2} \mathrm{D}_{3}$ has the major influence on intestinal absorption of $\mathrm{Ca}$. There is also evidence that both $24,25-(\mathrm{OH})_{2} \mathrm{D}_{3}$ and $1,25-(\mathrm{OH})_{2} \mathrm{D}_{3}$ may directly influence the parathyroid gland.

\section{Ca malabsorption}

Decreased $1,25-(\mathrm{OH})_{2} \mathrm{D}_{3}$ synthesis causes decreased intestinal absorption of Ca. Abnormal $\mathrm{Ca}$ absorption is further aggravated by low dietary $\mathrm{Ca}$ intake (Coburn et al. 1973; Varghese et al. 1973), although uraemic subjects can absorb $\mathrm{Ca}$ in similar amounts to normal subjects on normal diets when dietary $\mathrm{Ca}$ intake is elevated to $4^{-\mathrm{I}} \mathrm{Og} / \mathrm{d}$ (McDonald et al. $\mathrm{I} 964$ ). These observations suggest that there is a loss of normal adaption of $\mathrm{Ca}$ absorption and a lack of normal compensatory modulation to the skeletal needs for $\mathrm{Ca}$. This adaption appears to be mediated by vitamin $\mathrm{D}$. The factors responsible for reduced $\mathrm{Ca}$ absorption in chronic renal failure may be multiple, but reduced net $\mathrm{Ca}$ absorption may have an important role in the pathogenesis of renal osteodystrophy.

\section{Phosphate retention and secondary hyperparathyroidism}

Phosphate retention is considered to play an important role in causing hypocalcaemia. Bricker et al. (1969) proposed that 'secondary hyperparathyroidism in chronic progressive renal disease begins with the destruction of the first nephron'. Their hypothesis suggests that loss of nephrons 
leads to phosphate retention which in turn reduces the plasma $\mathrm{Ca}$ concentration and causes an increase in the secretion of PTH. This results in an increase in phosphate excretion and normalization of plasma phosphate level and a stepwise increase in PTH with every decrement in renal function.

Several observations support this hypothesis (Slatopolsky et al. 1972). Berlyne et al. (1973) attributed the lower incidence of renal osteodystrophy in undialysed CRF patients in Israel to their low-phosphate diet. It has also been shown that the decrease in plasma phosphate concentration obtained during treatment with phosphate binding agents is usually associated with a fall in the level of circulating i-PTH (Hill et al. 1973). In patients with severe osteitis fibrosa PTH itself by its effect on bone reabsorption can exacerbate hyperphosphataemia and render it refractory to treatment. The development of secondary hyperparathyroidism thus appears to begin early and progresses in severity with advancing renal failure (Fig. I).

\section{Additional factors}

Although hyperphosphataemia plays a major role in the pathogenesis and progression of renal osteodystrophy, there is now an increasing awareness that phosphate depletion may aggravate bone disease and cause osteomalacia. This may be due to over-treatment with phosphate binders (Baker et al. 1974) but in other instances is due to factors such as severe phosphate malabsorption, poor dietary intake and excessive dialysis losses (Ahmed et al. 1976).

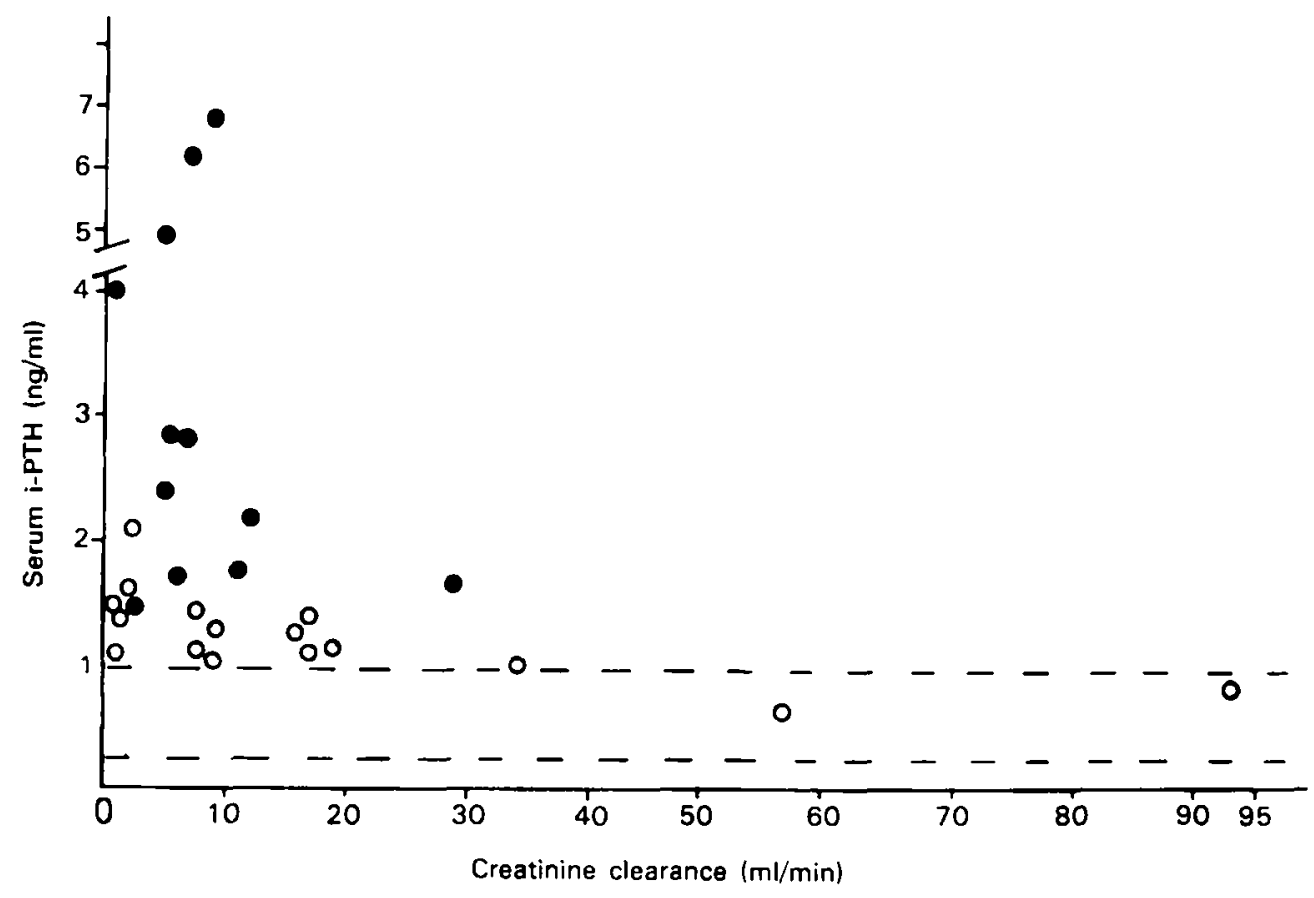

Fig. 1. Relationship between creatinine clearance and serum with PTH values in non-dialysed CRF patients with $(O)$ and without $(O)$ subperiosteal erosions (Arnaud, 1973). 
Other dietary factors may also be important in the development of renal osteodystrophy. Water-soluble vitamins are scarce in the diet of uraemic subjects (Kopple \& Swendseid, 1975) and it has also been shown that protein restriction may aggravate the deficiency of vitamin $\mathrm{C}$ and pyridoxine. Vitamin $\mathrm{C}$, vitamin $\mathrm{D}$ and pyridoxine are essential cofactors in the formation and maturation of collagen, and a normal collagen matrix is essential for normal skeletal function. Elevated serum vitamin A levels occur in uraemic subjects (Kopple \& Swendseid, 1975). This may be aggravated by the indiscriminate use of multivitamin preparations. Vitamin A may stimulate the parathyroid gland, and directly or indirectly cause $\mathrm{Ca}$ release from bone (Chertwo et al. 1974).

\section{Dialysis osteodystrophy}

Haemodialysis does not completely correct the uraemic state and does not restore plasma $\mathrm{Ca}$ and phosphate homoeostasis to normal. The deficiency of 1,25-(OH $)_{2} \mathrm{D}_{3}$ persists (Haussler \& McCain, 1977). Gastrointestinal absorption of $\mathrm{Ca}$ and phosphate, though variable, usually remains defective (Fig. 2). However, it is wrong to assume that metabolic bone disease developing in patients on MHT is necessarily similar to that found in non-dialysed chronic renal failure patients. Despite the histological similarities, the two diseases have different clinical courses, different rates of progression, and different prevalences (Moorhead $e t$ al. 1974).

The main component of dialysis osteodystrophy is osteitis fibrosa; osteomalacia being relatively uncommon. Bone disease in MHT patients progresses despite the maintenance of plasma $\mathrm{Ca}$, and magnesium and their fractions at concentrations which in a normal subject would be unlikely to be associated with either osteomalacia or hyperparathyroidism. (Varghese et al. 1973.) Dialysis patients may encounter numerous additional factors (Table $\mathrm{I}$ ) some of which may be outside the normal influence of the metabolic regulators of $\mathrm{Ca}$ and phospate homoeostasis.

Table I. Special factors in dialysis osteodystrophy

I. Dialysate calcium

2. Dialysate magnesium

3. Phosphate depletion

(a) Use of phosphate binders

(b) Loss during dialysis

(c) Severe phosphate malabsorption

(d) Poor dietary intake

4. Impurities in the water or chemicals used in the preparation of dialysis fluid

(a) Fluoride

(b) Aluminium

(c) Other contaminants

5. Type and frequency of dialysis

6. Drugs

(a) The influence of enzyme inducing drugs on vitamin $D$ metabolism, e.g. barbiturates

(b) Drugs modifying PTH secretion, e.g. $\beta$ blockers, cimetidine, vitamin A

(c) Heparin 
Vol. $3^{8}$

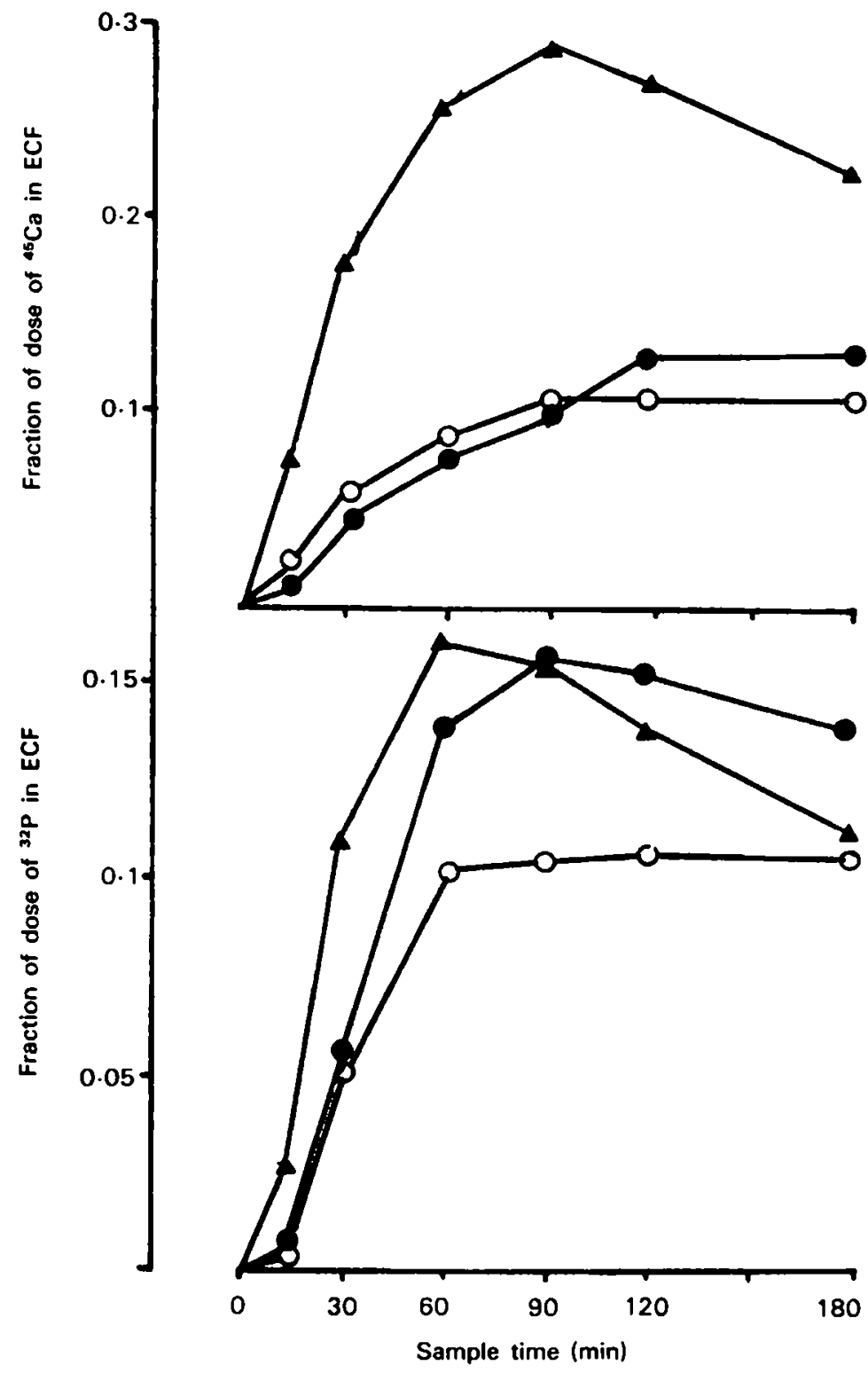

Fig. 2. Plasma activity of calcium and phosphate during $3 \mathrm{~h}$ absorption tests. ( $\Delta)$, controls; ( $)$ ), CRF patients on dialysis; (O), non-dialysed CRF patients.

\section{Management}

Despite the progress in the understanding of the pathogenesis of renal osteodystrophy there is still no unified approach to treatment. However, from an understanding of the pathogenesis several therapeutic measures are possible. The 
aims of these are to normalize plasma phosphate and Ca concentration, to suppress parathyroid glands, to normalize skeletal metabolism, and to avoid metastatic calcification. It is of importance to monitor the renal function in non-dialysed CRF patients, to ensure that the agents used (vitamin $\mathrm{D}$ compounds, and $\mathrm{Ca}$ supplements) have no adverse effect on residual renal function (Farrington et al. 1978).

\section{Phosphate binders}

Although it has been claimed that a proportional reduction of dietary phosphate with decline in renal function may delay the development of secondary hyperparathyroidism early in renal failure, this is not practicable. In severe renal failure phosphate binders are used with careful monitoring of phosphate levels. Increasing duration and frequency of dialysis may also aid control of plasma phosphate.

\section{Oral Ca supplements}

Because of the co-existence of poor dietary intake of $\mathrm{Ca}$ and $\mathrm{Ca}$ malabsorption, supplements should be given to increase the total dietary intake to approximately $1 \cdot 5^{-2} \cdot 0 \mathrm{~g} / \mathrm{d}$. Fletcher et al. $(1963)$ reported that external Ca balance in renal failure could be made positive by increasing the oral $\mathrm{Ca}$ intake, but this had no beneficial effect in correcting osteomalacia. This is in agreement with the observations of Eastwood et al. (1974).

\section{Dialysate $\mathrm{Ca}$}

Raising the concentrations of $\mathrm{Ca}$ in the dialysing fluid (approximately $6.0 \mathrm{mg} / 100 \mathrm{ml}$ ) is another way to keep the patients in a positive Ca balance. It has been suggested that bone disorders associated with secondary hyperparathyroidism can be prevented by the use of high dialysate $\mathrm{Ca}$ (Goldsmith et al. 1971). A number of studies have indicated short-term benefit from such strategies (Moorhead et al. 1975). However, Tatler et al. (1973) found no significant changes in the progressive development of bone reabsorption and vascular calcification when they used dialysate $\mathrm{Ca}$ concentrations of $6.5-7.5 \mathrm{mg} / 100 \mathrm{ml}$. Although there is no definite recommendation regarding the optimum concentrations of $\mathrm{Ca}$ in the dialysate, a concentration between $6 \cdot 5-7.5 \mathrm{~m} / 100 \mathrm{ml}$ seems to be desirable.

\section{Vitamin D compounds}

Since the pathogenesis of renal osteodystrophy suggests an effective vitamin $\mathrm{D}$ deficiency state, vitamin $\mathrm{D}$ and related compounds have a definite place in the treatment of renal osteodystrophy and this is specially important in patients with predominant osteomalacia, hypocalcaemia and after parathyroidectomy. Currently the forms of vitamin $D$ compounds available for clinical use include vit $D_{2}$, vit $D_{3}$, DHT, $1 a-\mathrm{OHD}_{3}$, and clinical trials are being done with other compounds $25-\mathrm{OHD}_{3}, 1,25-(\mathrm{OH})_{2} \mathrm{D}_{3}$ and $24,25-(\mathrm{OH})_{2} \mathrm{D}_{3}$. There is little evidence to indicate 
that vitamin $D_{2}$ differs in activity from vitamin $D_{3}$ in man. Pharmacologic doses of vitamin $D_{3}$ have been found to be effective in treating renal osteomalacia (Lumb et al. 1971). The individual requirement for vitamin $\mathrm{D}_{2}$ may vary widely from 0.1 to $5 \mathrm{mg} / \mathrm{d}$, and the dosage needs to be adjusted during the course of treatment. This dosage is far in excess of the daily normal adult requirement $(\mathrm{r} \cdot 9 \mu \mathrm{g} / \mathrm{d})$ and a real danger of toxicity exists. Dihydrotachysterol has been used in the treatment of renal osteodystrophy since the original observation of Liu \& Chu (1943). DHT has obvious structural similarities to $1,25-(\mathrm{OH})_{2} \mathrm{D}_{3}$, because of the possibility of rotating the ' $A$ ' ring through $180^{\circ}$ bringing the $3 \beta$ hydroxyl group into a pseudo $I$ position (Hallick \& DeLuca, 1972). This may explain why DHT is more effective than vitamin $D_{2}$ or vitamin $D_{3}$ in patients with chronic renal failure. Our experience of treating $\mathrm{CRF}$ patients with some of these compounds is given in the next sections.

\section{Dihydrotachysterol (DHT)}

Fifteen CRF patients were treated with $0.25 \mathrm{mg}$ DHT/d for 18 months. Thirteen patients were on haemodialysis and the remaining two had end stage CRF (creatinine clearance (C.Cr) $6 \mathrm{ml} / \mathrm{min}$ ). In addition to DHT they were given $4 \mathrm{~g} \mathrm{Ca} \mathrm{CO}_{3} / \mathrm{d}$. Plasma phosphate was controlled by aluminium hydroxide therapy. There was no significant increase in plasma phosphate during the course of this study (Fig. 3). There was a gradual rise in plasma $\mathrm{Ca}$ and it became statistically significant from the second month $(P<0.025)$. However, at no point did the patients become hypercalcaemic. Plasma hydroxyproline showed a significant $(P<0.02)$ fall from the first month, even before there was a significant change in plasma Ca. Plasma alkaline phosphate only showed a significant change $(P<0.01)$ 5 months after starting treatment. This response in alkaline phosphatase was slower than that which was seen with either $1 a-\mathrm{OHD}_{3}$ or $1,25-(\mathrm{OH})_{2} \mathrm{D}_{3}$. Iliac crest hone biopsis were available in ten patients before and after treatment (Fig. 4). These showed a marked reduction in osteoid volume in all patients. However, improvement in mineralization front was seen in only five patients. There was a reduction in active reabsorption surfaces in seven patients.

\section{$\mathrm{r} \alpha-\mathrm{OH}$ cholecalciferol}

Eleven patients with CRF (mean C.Cr 1 I $.8 \pm 8.8 \mathrm{ml} / \mathrm{min}$ ) were treated for periods of 6 to 15 months with oral doses of $1 \alpha \mathrm{OHD}_{3}(0.25 \mu \mathrm{g}-1 \mu \mathrm{g} / \mathrm{d}$, mean dose $0.4 \mu \mathrm{g} / \mathrm{d}$ ). The starting dose was $0.25 \mu \mathrm{g} / \mathrm{d}$ increasing up to 0.5 or $\mathrm{I} \mu \mathrm{g} / \mathrm{d}$. Oral Ca carbonate (up to $2.5 \mathrm{~g} / \mathrm{d}$ ) and aluminium hydroxide preparations were also prescribed.

Ca absorption was increased in direct proportion to the dose of $1 \alpha-\mathrm{OHD}_{3}$ used (Fig. 5) though there was no over-all effect of phosphate absorption on any dose level. This may reflect a fundamental difference in the control mechanism of intestinal $\mathrm{Ca}$ and phosphate transport, as previously suggested (Farrington et al. 1979). Plasma Ca increased significantly in response to treatment, but there was no effect on plasma phosphate levels (Fig.6); Alkaline phosphatase decreased 

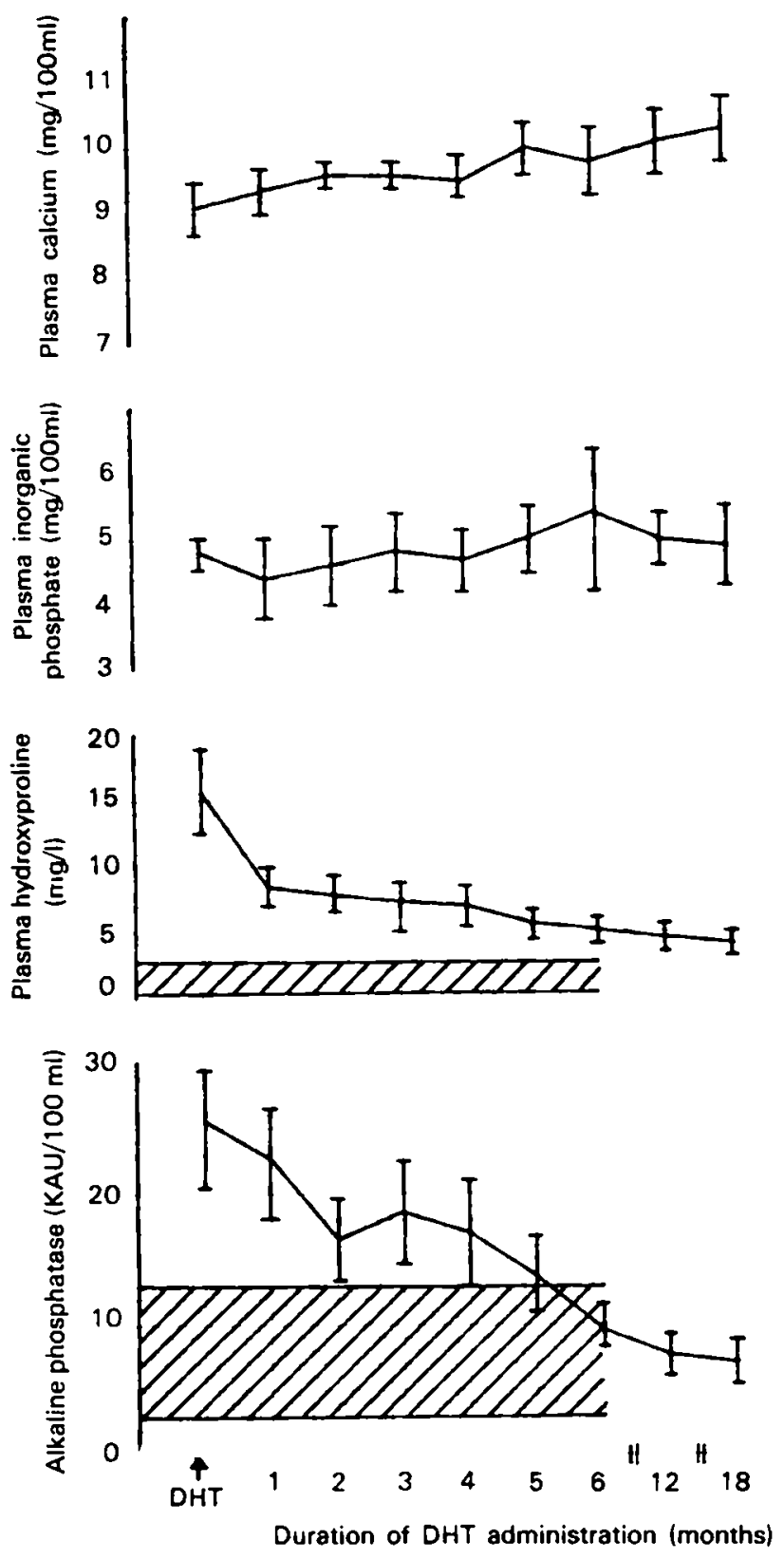

Fig. 3. Biochemical responses to treatment with dihydrotachysterol (DHT). 

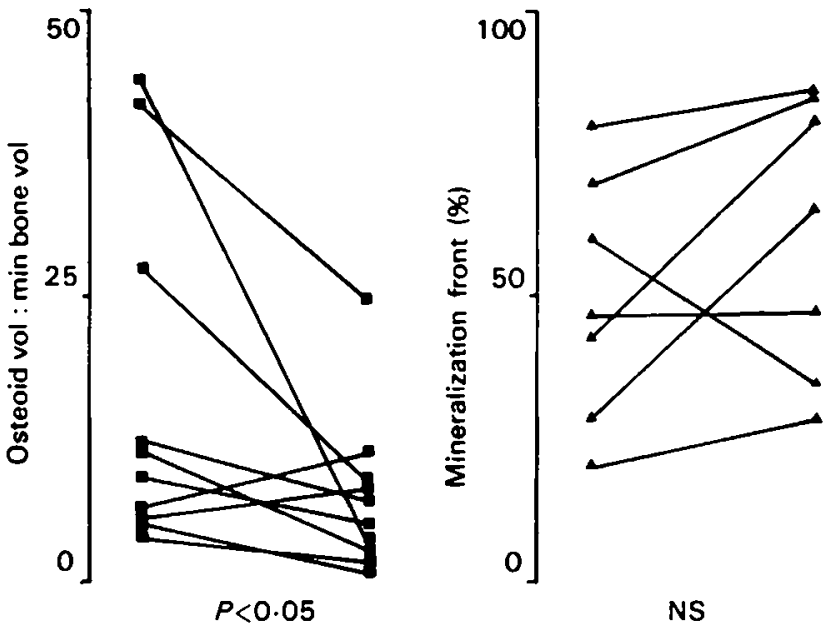
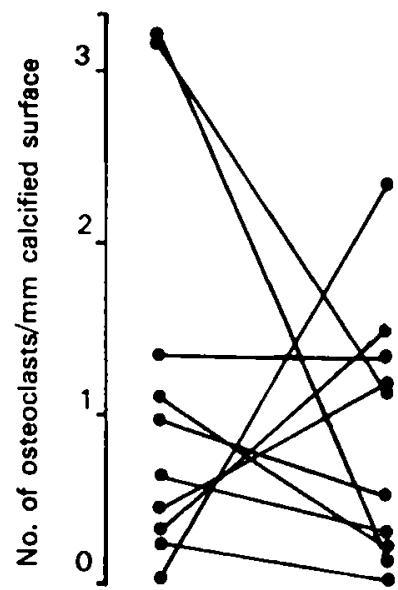

NS

Fig. 4. Changes in histological measurements in response to treatment with dihydrotachysterol (DHT). NS, not significant.

significantly. A significant reduction in bone turnover occurred, as indicated by significant reductions in osteoid volume and active surfaces (Fig. 7). However, there was no significant effect on mineralization front as assessed by single tetracycline labelling. This supports the suggestions of Bordier et al. (1978) that other metabolites of vitamin $\mathrm{D}$ such as $25-\mathrm{OHD}_{3}$ and $24,25-(\mathrm{OH})_{2} \mathrm{D}_{3}$ may be important in the reversal of the mineralization defects in this condition.

\section{$\mathrm{I}, 25-(\mathrm{OH})_{2}$ cholecalciferol}

Oral $1,25-(\mathrm{OH})_{2} \mathrm{D}_{3}(0.5 \mu \mathrm{g} / \mathrm{d})$ and $4 \mathrm{~g}$ of $\mathrm{Ca}$ carbonate/d were given to five CRF patients for $4^{-16}$ months. This treatment was found to be effective in correcting intestinal $\mathrm{Ca}$ malabsorption in all patients. Plasma alkaline phosphatase, plasma hydroxyproline and i-PTH concentrations showed significant reductions. The fall in i-PTH concentration seen was independent of changes in the plasma $\mathrm{Ca}$, suggesting a direct action of $1,25-(\mathrm{OH})_{2} \mathrm{D}_{3}$ on parathyroid glands. Bone histology showed marked improvements (Ahmed et al. 1978).

\section{Parathyroidectomy}

With increasing time on dialysis a growing number of patients may develop persistent hypercalcaemia, progressive elevations in the concentration of plasma phosphate, alkaline phosphatase, hydroxyproline and i-PTH, and radiological and histological evidence of severe osteitis fibrosa. These patients require subtotal or total parathyroidectomy.

Hyperparathyroidism in dialysis patients thus appears to be of a progressive nature (Fig. 8) in spite of the short-term control obtained by phosphate binders, oral $\mathrm{Ca}$ supplements, high dialysate $\mathrm{Ca}$ and vitamin $\mathrm{D}$ compounds. This eventual 'escape' from control may not be obvious from short-term studies. 


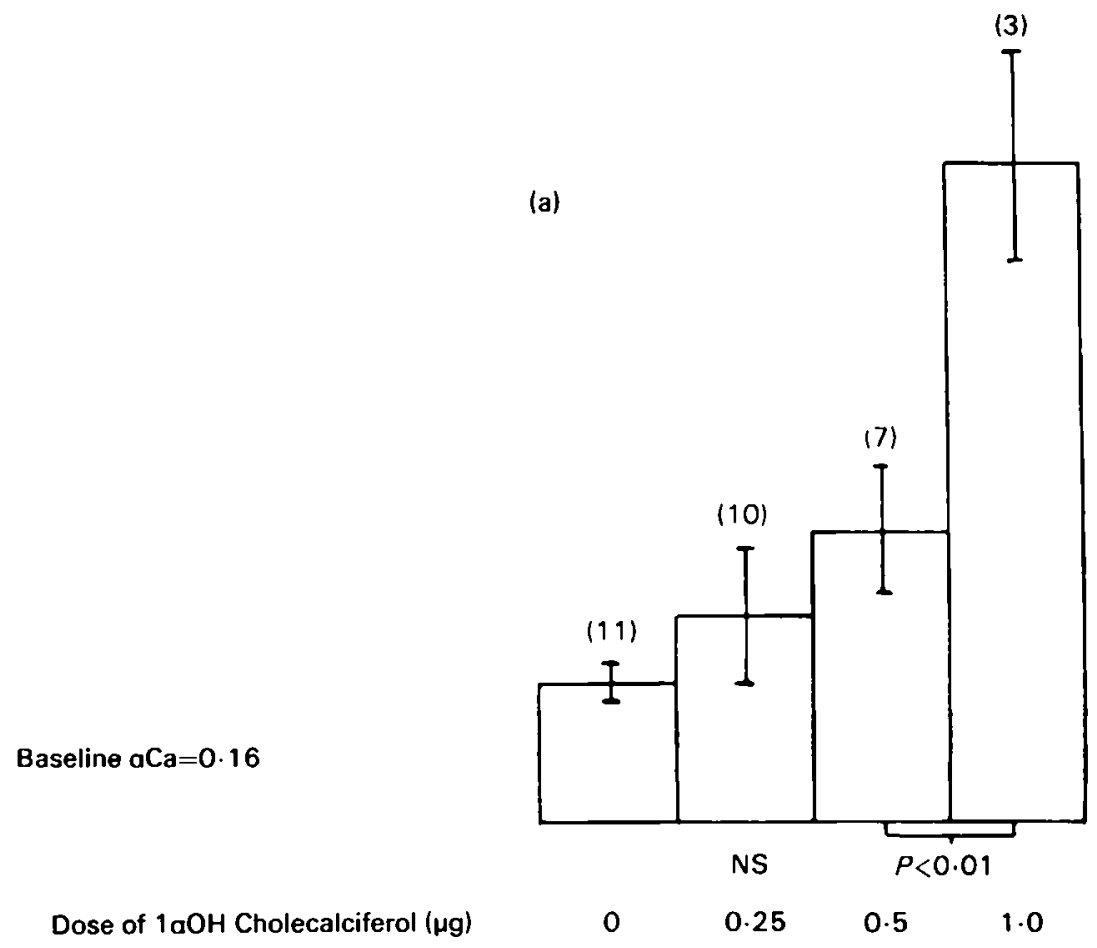

(b)

Baseline $\mathrm{aPO}_{4}=0.31$

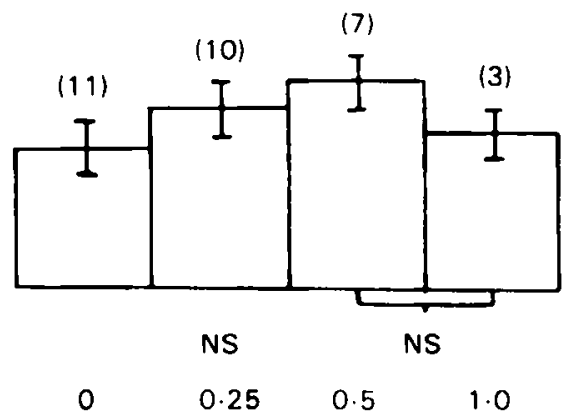

Fig. 5. Calcium (a) and phosphate (b) absorptions in response to treatment with raOH cholecalciferol. Number of observations in parentheses. Vertical bars represent sem. 

(11)
(11)
(11)
(10)
(8)
(6)
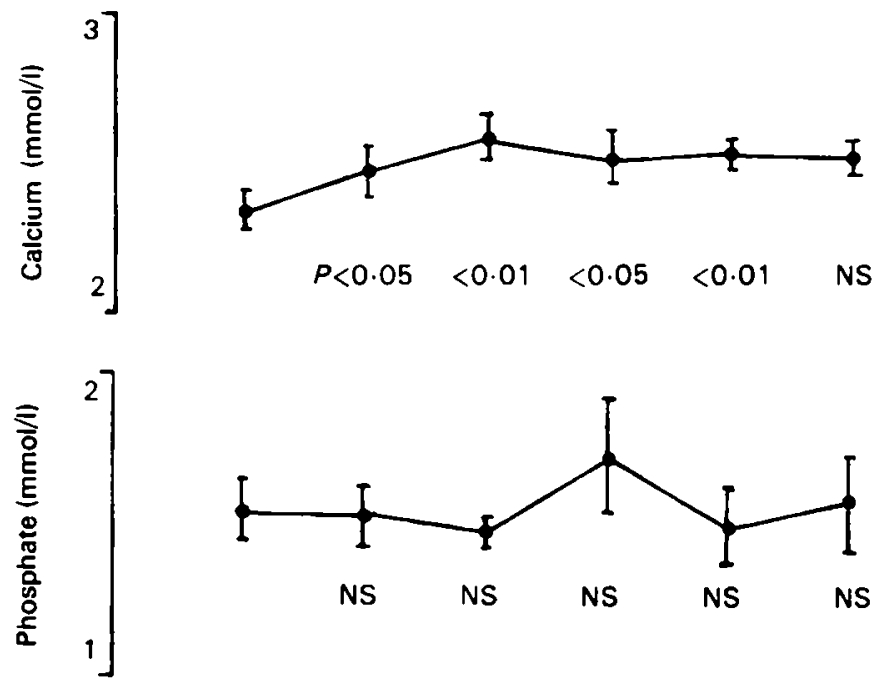

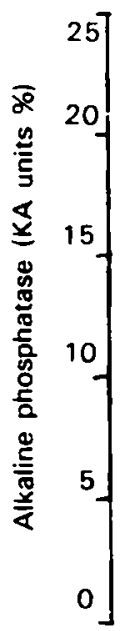

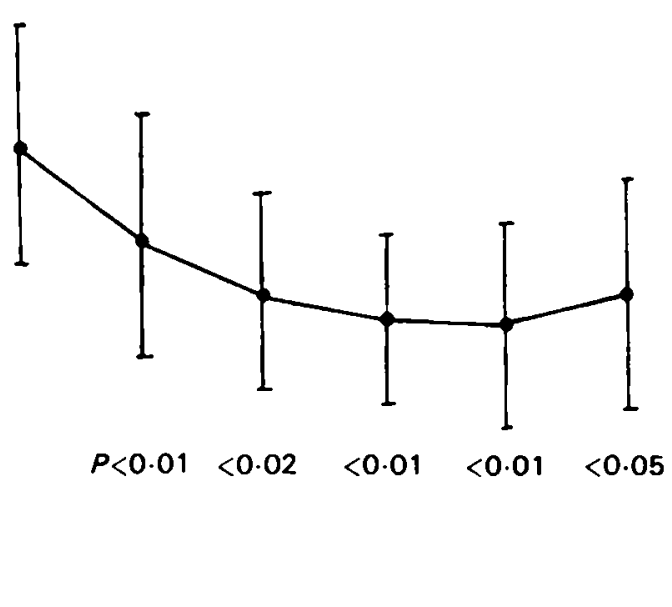

Duration of $\begin{array}{lllllll}\text { treatment (months) } & 0 & 3 & 6 & 9 & 12 & 15\end{array}$

Fig. 6. Biochemical responses to treatment with $1 \alpha \mathrm{OH}$ cholecalciferol. Points are mean values with their SEM represented by vertical bars; number of patients in parentheses. 

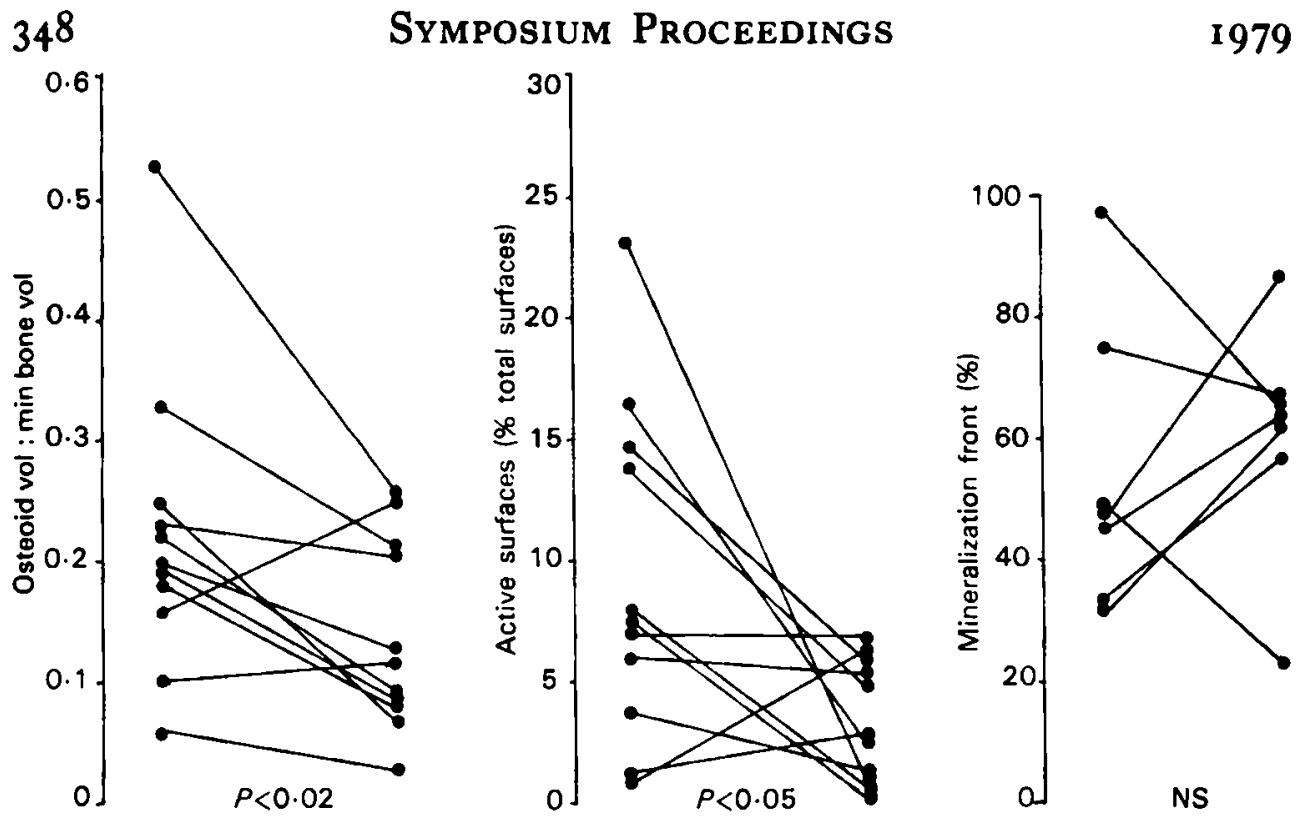

Fig. 7. Changes in histological measurements in response to treatment with $1 \alpha \mathrm{OH}$ cholecalciferol. Active surfaces refer to the sum of active resorption and active formation surfaces.

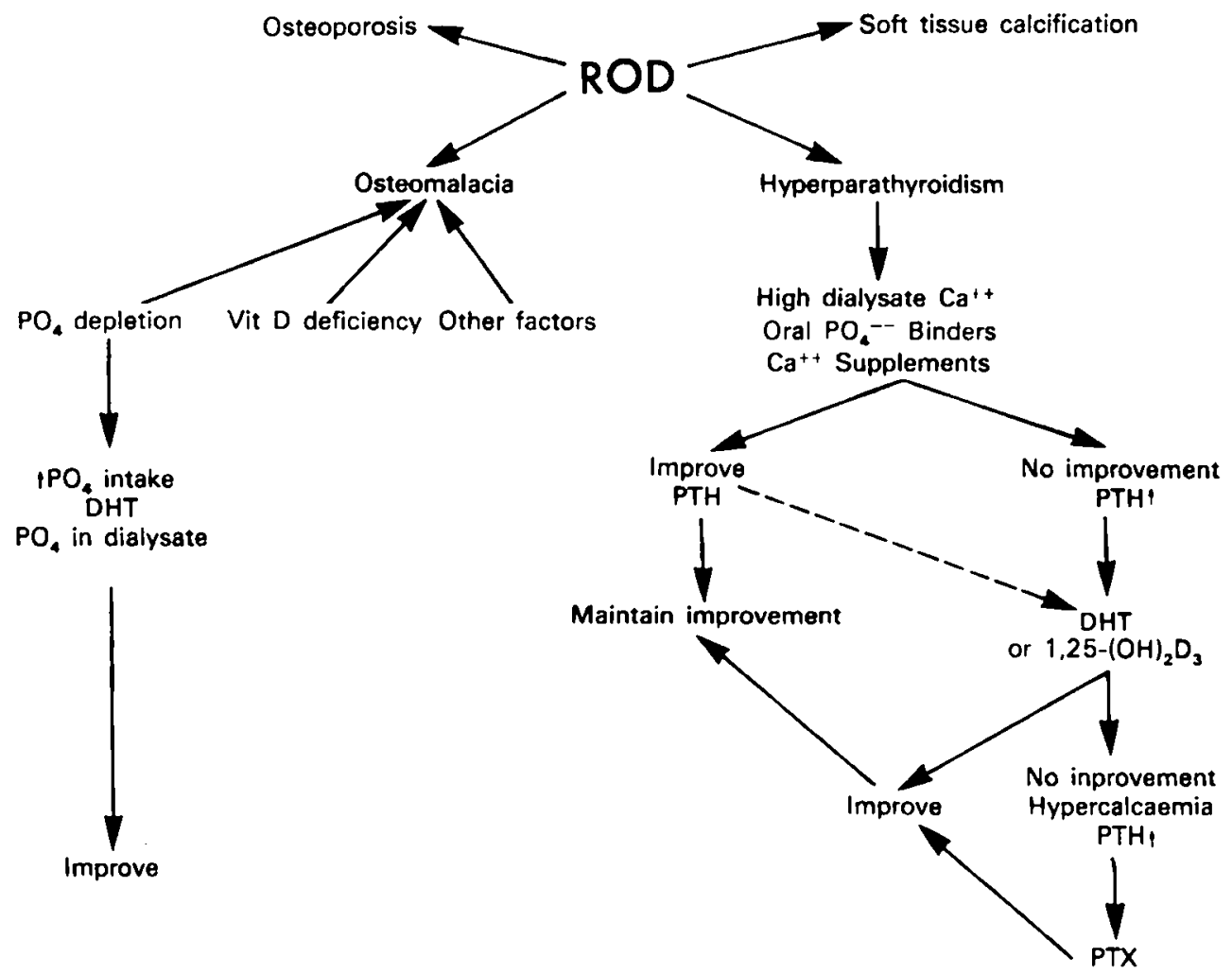

Fig. 8. Schematic representation of the responses of haemodialysis patients to various therapeutic interventions for controlling metabolic bone disease. Escape from the therapeutic control and the progression of the bone disease on dialysis is also shown. 


\section{REFERENCES}

Ahmed, K. Y., Varghese, Z., Wills, M. R., Meinhard, E. A. \& Moorhead, J. F. (1978). Lancet i, 629 .

Ahmed, K. Y., Varghese, Z., Wills, M. R., Meinhard, E. A., Skinner, R. K., Baillod, R. A. \& Moorhead, J. F. (1976). Lancet ii, 439.

Arnaud, C. D. (1973). Kidney Int. 4, 89.

Avioli, L. V. (1978). Dialysis and Transplantation 7, 244.

Avioli, L. V., Birge, S., Lee, S. W. \& Slatopolsky, E. (1968). J. clin. Invest. 47, 2239.

Baker, L. R. I., Ackrill, P., Cattell, W. R., Stamp, T. C. B. \& Watson, L. (1974). Br. Med. J. 3, 150.

Berlyne, G. M., Ben-Arie, J., Epstein, N., Booth, E. M. \& Yagil, N. (1973). Nephron 10, 141.

Bordier, Ph.J. Rasmussen, H., Marie, P., Miravet, L., Gueries, J. \& Ryckwaert, A. (1978). J. clin. Endocr. Metab. 46, 284.

Bordier, Ph.J., Tun-Chot, S., Eastwood, J. B., Fournier, A. \& deWardner, H. E. (1973). Clin Sci. 44,33 .

Bricker, N. S., Slatopolsky, E., Reiss, E. \&z Avioli, L. V. (1969). Archs intern. Med. 123, 543.

Brickman, A. S., Coburn, J. W. \& Massry, S. G. (1974). Ann. intern Med. 80, 16r.

Chertwo, B. S., Williams, G. A., Kiani, R., Stewart, K. L., Hargis, G. K. \& Flayter, R. L. (1974). Proc. Soc. exp. Biol. Med. 147, I6.

Coburn, J. W., Koppel, M. H., Brickman, A. S. \& Massry, S. G. (1973). Kidney Int. 3, 264.

Cochran, M., Bulusu, L., Horsman, A., Stasiak, L. \& Nordin, B. E. C. (1973). Nephron 10, 113.

David, S. D. (1975). Am. J. Med. 58, $4^{8}$.

Del uca, H. F. (1973). Kidney Int. 4, 80.

Eastwood, J. B., Bordier, P. J., Clarkson, E. M., Tun-Chot, S. \& deWardner, H. E. (1974). Clin. Sci. mol. Med. 47, 23.

Fastwood, J. B., deWardner, H. E., Gray, R. W. \& Lemann, Jr. J. L. (1979). Lancet i, i 377.

Eastwood, J. B., Harris, E., Stamp, T. C. B. \& deWardner, H. E. (1976). Lancet ii, 1209.

Ellis, H. A. \& Peart, K. M. (1973). f. clin. Path. 26, 83.

Farrington, K., Skinner, R. K., Varghese, Z. \& Moorhead, J. F. (1979). Lancet i, 321.

Farrington, K., Varghese, Z. \& Moorhead, J. F. (I978). Lancet ii, 94I.

Farrington, K., Varghese, Z., Newman, S. P., Ahmed, K. Y., Fernando, O. N. \& Moorhead, J. F. (1978). Br. Med. F. I, 712.

Fletcher, R. F., Jones, J. H. \& Morgan, D. B. (1963). Q. fl Med. 32, 321.

Goldsmith, R. S., Furszyfer, J., Johnson, W. J., Fournier, A. E. \& Amaud, C. D. (1971). Am. . Med. 50, 692.

Hallick, R. B. \& DeLuca, H. F. (1972). f. biol. Chem. 247, 91.

Haussler, M. R. (1975). In Vitamin $D$ and Problems Related to Uraemic Bone Disease [A. W. Norman, K. Schaefer, H. G. Grigoleit, D. V. Herrath, and E. Ritz, editors], Proceedings of the and Workshop on vitamin D, Weisbaden, Germany, October 1974, p. 25. Berlin: Walter, de Gruyter.

Haussler, M. R. \& McCain, T. A. (1977). New Engl. J. Med. 297, 1041.

Hill, A. V. L., Thein-Than, Cook, D. B., Kerr, D. N. S. \& Latner, A. L. (1973). Clin. Nephrol. 1, 284 .

Hruska, K. A., Kopelman, R., Rutherford, W. E., Klahr, S. \& Slatopolsky, E. (1975). f. clin. Invest. 56, 39 .

Jubiz, W., Haussler, M. R., McCain, T. A. \& Tolman, K. C. (1977). J. clin. Endocr. Metab. 44, 617.

Kaye, M. \& Silverman, M. (1965). F. Lab. clin. Med. 66, 535.

Kleeman, C. R. \& Better, O. S. (1973). Kidney Int. 4, 73.

Kopple, J. D. \& Swendseid, (1975). Kidney Int. 7(S), S-79.

Lee, S. W., Russell, J. E. \& Avioli, L. V. (1977). Science 195, 994.

Liu, S. H. \& Chu, H. I. (1943). Medicine 22, 103.

Lumb, G. A., Mawer, E. B. \& Stanbury, S. W. (1971). Am. J. Med. 50, 421.

McDonald, S. J., Clarkson, E. M. \& deWard́ner, H. E. (I964). Clin. Sci. 26, 27.

Massry, S. G., Coburn J. W., Lee, D. B. N., Jowsey J. \& Kleeman, C. R. (1973). Ann. intern. Med. 78,357 . 
Massry, S. G., Dua, S., Garty, J. Friedler, R. M. (1978). Mineral Electrolyte Metab. I, 172. Mawer, E. B., Backhouse, J., Taylor, C. M., Lumb, G. A. \& Stanbury, S. W. (1973). Lancet i, 626. Moorhead, J. F., Tatler, G. L. V., Baillod, R. A., Varghese, Z., Wills, M. R. \& Farrow, S. C. (1974). Br. Med. 7. 4, 557.

Moorhead, J. F., Varghese, Z., Tatler, G. L. V., Baillod, R. A., Ku, G., Sweatmen, A. J. \& Wills, M. R. (1975). Proc. Eur. Dialysis and Transplant Ass. 11, 465.

Offerman, G., Von Herrath, D. \& Schaefer, K. (1974). Nephron 13, 269.

Pierides, A. M. (1978). Dialysis and Transplantation 7, 725 .

Slatopolsky, E., Caglar, S., Gradowska, L., Canterbury, J., Reiss, E. \& Bricker, N. S. (1972). Kidney Int. 2, 147.

Stanbury, S. W., Lumb, G. A. \& Mawer, E. B. (1969). Archs intern. Med. 124, 274.

Tatler, G. L. V. Baillod, R A., Varghese, Z., Young, W. B., Farrow, S., Wills, M. R. \& Moorhead, J. F. (1973). Br. Med. F. 4, 315.

Varghese, Z., Moorhead, J. F. \& Wills, M. R. (1973). Lancet ii, 985.

Wills, M. R., Jenkins, M. V. \& Moorhead, J. F. (1975). In Opuscula Medico-Technica Lundensia $X I V$, [R. Maiorca and T. Lindholm, editors], p. I 37. Lund, Sweden: R.A.H.M.S. 